\title{
The finale of a war criminal's existence: mysteries surrounding Oskar Dirlewanger's death
}

Zarys treści: Śmierć Oskara Dirlewangera była owiana tajemnicą. Odkrycie dokumentów w Ludwigsburgu przed prawie trzema dekadami przez niemieckiego historyka Hansa-Petera Klauscha przybliżyło do prawdy. Niniejszy artykuł jest próbą odpowiedzi na pytanie zasygnalizowane w 1993 roku, gdzie służyli „polnischen Wachtmannschaft”. Podjęta próba wyjaśnienie autorstwa oparła się kwerendzie w dwóch zagranicznych archiwach oraz trzech polskich. Efekty długo kazały na siebie czekać - a część wniosków nie może być nadal nadal ujawniona, opierając się jedynie na uczestnikach wydarzeń w Altshausen.

Content outline: The death of Oskar Dirlewanger was shrouded in mystery. The discovery of documents in Ludwigsburg almost three decades ago by the German historian Hans-Peter Klausch brought us closer to the truth. The present article is an attempt to answer the question raised in 1993 as to who were the "Polnischen Wachmannschaft." The attempt to identify the perpetrators was based on a query in two foreign and three Polish archives. The results came to light only after extensive research, and some conclusions are still beyond reach, as they depend solely on the participants of the events in Altshausen.

Slowa kluczowe: II wojna światowa, Oscar Dirlewanger, francuska polityka okupacyjna, okupacja Niemiec, klęska III Rzeszy, 1 Armia francuska

Keywords: Second World War, Oskar Dirlewanger, French occupation policy, occupation of Germany, defeat of the Third Reich, French First Army

Did the ruthless pacifier of Belarusian villages and the capital of Poland deserve harsh treatment? Like many other German war criminals, Oskar Dirlewager sought to evade responsibility by attempting to blend in with the crowds of refugees. It appears that his destination of choice was Switzerland. The attempt to solve the mystery of the last weeks of Dirlewanger's life poses a further challenge for a full clarification of the uncertainties related to the Polish episode near the end of the earthly existence of the German war criminal.

The final fate of the injured Dirlewanger, after he had left the military hospital, is shrouded in mystery. One document mentions his visit to Gottlob Berger's house 
in Berlin on 15-20 March 1945 and his return to his parents' house in Esslingen am Neckar. Others would point to an immediate evacuation towards south-west Germany, to the town of Altshausen in Württemberg. In any case, Dirlewanger travelled around Germany without any difficulty in these last tense weeks when "defeatists" were being hunted and hanged. Reports on the end of Dirlewanger's life are equally uncertain and contradictory. Some people suspected him of successfully escaping to Egypt, where he was supposed to be training the local police force in cooperation with Otto Skorzeny. In 1960, all the questions found a surprising answer. ${ }^{1}$ It turned out that Dirlewanger had been killed in the aforementioned town in Württemberg, at the Detention Centre Altshausen (Centre de détention d'Altshausen), a former oast house, later a coach house and stable, adjacent to the local town hall (Rathaus). This representative urban building was occupied by Second Lieutenant [Sous-lieutenant] Hoffmann, the garrison officer of Altshausen [Officier de Garnison de la Place d'Altshausen]. On the night of 4/5 June, the criminal was taken three times for "interrogation" during which he was beaten in the corridor. ${ }^{2}$

The French occupation authorities resided in the town hall, located near Schloss Altshausen, the seat of Philipp Albrecht, Duke of Württemberg. ${ }^{3}$ When in 1934 Duke Philip Albrecht had refused to fly the swastika flag at his palace, the Kronprinzenpalais in Stuttgart, the National Socialists forced him to leave the city with his family and move to the Altshausen palace for opposing the regime. ${ }^{4}$

We do not know how Dirlewanger reached Althausen. After leaving the field hospital, he ended up in Berlin on 15-20 March 1945, where he met with

1 Bundesarchiv Ludwigsburg [hereinafter: BAL], B162/16592, fol. 104-112, Materialsammlung betr. Sondereinheit Dirlewanger - Bd. 1 T. 1 Unterlagen verschiedener Proveniezen zu Oskar Dirlewanger: Institut Für Gerichtliche Medizin Der Universität Freiburg, Prof. Dr. med. G. Weyrich, An die Staatsanwaltschaft Ravensburg, Betr: Ermittlungsverfahren gegen Dr. Dirlewanger, Oskar, wegen Mordverdacht, 24.11.1960; H.-P. Klausch, Antifaschisten in SS-Uniform. Schicksal und Widerstand der deutschen politischen KZ-Häftlingen Zuchthaus- und Werhmachtsgefangenen in der SS- Sonderformation Dirlewanger, Bremen, 1993, p. 303, and French L. MacLean, The Cruel Hunters. SS-Sonderkommando Dirlewanger. Hitler's Most Notorious Anti-Partisan Unit, Atglen, 1998, p. 223.

2 Archiwum Instytutu Pamięci Narodowej [hereinafter: AIPN], GK 164/1711, fol. 16-17, GKBZN, Case file: dr Dirlewanger Oskar, Copie certifiée conforme à l'original, 30.10.1947; Le Sous-lieutenant Hoffmann, Officier de Garnison de la Place d'Altshausen à Monsieur le Chef de Bataillon, Commandant le 4eme Bataillon du 9eme Regiment de Zouaves; 08.06.1945; H.-P. Klausch, op. cit., p. 315, F. L. MacLean, op. cit., p. 225 and Д. Жуков, И. Ковтун, Охотники за партизанами. Бригада Дирлевангера, Москва, 2013, pp. 407-408.

${ }^{3}$ Georg Philipp Albrecht Carl Maria Joseph Ludwig Hubertus Stanislaus Leopold Herzog von Württemberg.

${ }^{4}$ A castle of the Teutonic Order (Deutschordensschloß), the only Baroque monastic palace of the renowned architect Johann Caspar Bagnato. The complex was built in the 18th century and is now the residence of the Ducal House of Württemberg. The castle garden with sculptures of Diane, Duchess of Württemberg, and St. Michael was renovated in 2000 and is open to the public; see: E. Fritz, "Das Haus Württemberg und der Nationalsozialismus. Motive des Widerstands gegen Hitler und seine Bewegung," in: Adel und Nationalsozialismus im deutschen Südwesten, ed. Ch. Dowe, Stuttgart-Leinfelden-Echterdingen, 2007, p. 139. 
SS-Obergruppenführer Gottlob Berger for the last time. We do not know exactly what they talked about, but the impending finale of the war urged them to cover their own traces as effectively as possible. Dirlewanger then returned from the German capital to his family home in Esslingen am Neckar. He devoted the first half of April to the retrieval of stolen and received items from his parents' house. The loot was to be hidden until better times. Soon afterwards, on 22 April, he moved to Allgäu-Imenstadt, in south-western Bavaria (then Gau Schwaben), to the nearby hunting grounds of the famous industrialist from Württemberg, Robert Bosch (a friend of Berger's). Here Dirlewanger got rid of his SS-Oberführer uniform and exchanged it for civilian clothes. Then he vanished for a few weeks. Undoubtedly, he travelled to the small town of Althausen, $80 \mathrm{~km}$ away, to disappear from public sight. Lake Constance and the nearby Swiss border were only 40 $\mathrm{km}$ away. It is possible to link Dirlewanger with one Altshausen resident, Christian Häberl. He was alleged to have been sent to Dirlewanger's unit as a cook in order to rehabilitate himself for the murder of an African man (a French colonial POW?). ${ }^{5}$ This provided Dirlewanger with shelter in the town. It should be noted that just three days after the surrender of Germany, roadside checks and inspections began on the entrances and exits of warehouses in the French zone. And in the fourth week of the occupation, the French began to seal the border with Austria and Switzerland. These activities were carried out on two roads that intersected in the small Württemberger town of our interest: Messkirch-PfullendorfOstrach-Altshausen-Weingarten-Ravensburg-Wangen in Allgäu-Imenstadt and Sigmaringen-Herbertingen-Bad Saulgau-Althausen. ${ }^{6}$

Meanwhile, fate worked more in favour of an anonymous soldier than the commander of SS-Sdr. Dirlewanger, as he remembered in postwar diaries: "We arranged some civilian clothing and threw our uniforms into a pit. [...] At night we scampered along, like so many other soldiers apparently, from village to village and through forests and fields to the Harz. We continually encountered individuals or small groups that also had set out on their own. We didn't talk much. We always tried to cover as much ground as possible at night. And we were actually

\footnotetext{
${ }^{5}$ One German journalist recalls an interesting regionalist book describing the end of the Nazi dictatorship in Württemberg: S. Emmrich, D. Breucker, P. Eitel, Kriegsende und Neubeginn. Das Jahr 1945 in Ravensburg, Weingarten und Umgebung - Taschenbuch, Ravensburg, 1996, see: B. Baur, "Kriegsverbrecher in Altshausen zu Tode gefoltert," in: Schwäbische Zeitung Altshausen, 5 June 2015, avilable at: https://www.schwaebische.de/landkreis/landkreis-ravensburg/altshausen_artikel,kriegsverbrecher-in-altshausen-zu-tode-gefoltert-_arid,10245358.html [accessed: 10 Jun 2018].

${ }^{6}$ Service historique de la Défense - Fonds de l'armée de Terre (à Vincennes) [hereinafter: SHD Vincennes], 10P/193-22, no fol., lére Armée Française, 3eme Bureau, No 2.579/3-US, Compte Letter of Transmittal, Special Instruction No. 215 on the closing of the Austro-German Frontier, Ref. Nr. 647/OP-3 + Special Instruction for participation of First French Air Corps in the closing of the German frontiers, Ref. No. 648/OP-3; 27.05.1945, and 10P/299 [1er Corps d'Armée, E.M., 4e Bureau], no fol. 1er Corps d'Armée, Etat-Major, 4e Bureau, No. 1891/4TC, Directives pour les services No. 3; 11.05.1945; and H.-P. Klausch, op. cit., p. 303.
} 
lucky that we didn't fall into the hands of Americans, because we couldn't see anything. We didn't know whether there were any guard posts out there somewhere. We were very lucky and actually made it to a little town near Mansfeld."

It was precisely in the Württemberg town of Altshausen that Dirlewanger was to fall victim to French or French colonial or Polish guards [Polnischen Wachmannschaften] at the local prison referred to as the "detention centre." The former group had already murdered prisoners in Altshausen before, while the Poles may have found out who was imprisoned there and decided to take advantage of the opportunity for revenge. The only question is: what could the Polish communists from the French Communist Party (Parti communiste français, PCF) have known about Dirlewanger? It would be worth putting forward the research question as to the extent to which Dirlewanger was known or even recognised by Poles in the years 1944-45 (in this case, Polish emigrants in France who knew little about the occupied homeland or the Warsaw Uprising). Inquiries into the uprising press do not show him being prominently featured; he did not stand out in the insurgent reports, nor in the "Information Bulletin," his unit being treated as yet another SS regiment - there was even less or no information in the French communist newspaper L'Humanité. Perhaps it is a possible explanation that Dirlewanger had found himself in a town with strong with a strong possible presence of deported Polish Jews or Poles who knew or remembered him and accidentally passed on this information to Rathaus Altshausen at a time when unplanned guard duty was performed there by the "Polnischen Wachmannschaften"? The second possible version of events mentions a Jewish camp survivor who had ended up in Württemberg (most likely the German forced labour camp in Stary Dzików, GG Zwangsarbeitslager - ZAL Dzikow). Was he the one who identified the German war criminal? Or maybe it was more about the belief of the guards that the sturdy elderly man could be hiding a treasure? The Polish guards would gladly take care of it, as they did with many other items stolen during the several months of occupation of Württemberg. The testimonies of Jan Gerhard, signalling the possibility of a third source of witnesses, may also serve as a hint: "Occasionally, the Group was contacted by Poles who had been working in Germany, as well as Poles from France, who wished to join the Group after its formation as a regular unit of the French army. Neither I, nor Major JELE[N] or even THEVENON had the right to recruit these people as the lists of soldiers had been approved and closed. [...] The French could use such a concentration of Poles, especially looters etc., by our units against us." 8

7 The SS-Sonderkommando "Dirlewanger": A Memoir, ed. R. Michaelis, Atglen, 2013, p. 96 [Erinnerungen an das SS-Sonderkommando „Dirlewanger," ed. R. Michaelis, Berlin, 2011, p. 102.].

8 Some hope for clarification has been found in the fate of Abraham Bravermann (b. 3 May 1921, Warsaw), Isidor Gilbert (b. 1 October 1920, Ciechanów), Wolf Gimpel (b. 10 July 1920, Bełżyce) and especially Majer Cukierman, son of Szulim, born on 15 February 1925. The latter was a Polish citizen of Jewish origin who was imprisoned in the Radom Ghetto (Rest-Ghetto) until 
Before describing the last days of Oskar Dirlewanger, it is necessary to clarify the question of the surviving Jewish prisoner. Obviously, there is no way of identifying him, but it has been possible to determine how concentration camp prisoners emerged in the quiet and peaceful town of Altshausen. This was related to the German practice of organising so-called "death marches" from camps that were to be occupied by the Allies. In the case of Altshausen, it was KL Bisingen, ${ }^{9}$ which operated as the external camp for KL Natzweiler-Struthof. The route of the over $100-\mathrm{km}$ long march led from Bisingen through Schömberg (KL Dautmergen in the Schömberg area)-Deilingen-Bärenthal-Beuron/Fridingen-Messkirch-WaldAach-Linz-Ostrach-Hoßkirch-Eichstegen and Ebenweiler. The column of 200 prisoners guarded by SS soldiers (Wachmann) reached Altshausen on 22 April 1945, where where after closing them in the barn, their German guards fled the site. The Württemberg town was seized on the same day following minor clashes. As they were advancing to the south-west, the units of the French 1st Army left only a small occupation garrison (unfortunately, we do not know whether Souslieutenant Hoffmann was already in command back then). The French appointed

27 July 1944, and then was held in German concentration camps: Vaihingen an der Enz from August 1944 to November 1944, Schömberg from November 1944 to April 1945, and finally in Althausen (Württemberg) since 23 April 1945. Unfortunately, in the available testimony he refers mostly to the Radom Ghetto. All the above mentioned men were transferred from ghettos and concentration camps in the General Government to camps in Germany, and finally ended their ordeal in Altshausen in April 1945, vide: AIPN, BU 2386/14475, fol. 105, Protokół przesłuchania podejrzanego Gerharda Jana; 5. 05. 1954; Sz 753/450, fol. 1-6, Odpis protokołu przesłuchania świadka nr 358 dot. Cukierman Majer, and V. Mall, Die Häftlinge des KZ-Außenlagers Hailfingen/ Tailfingen: Daten und Porträts aller Häftlinge, Norderstedt, 2014, p. 58 [Abraham Bravermann], pp. 128-129 [Isidor Gilbert], pp. 129-131 [Wolf Gimpel]..

9 KL Bisingen and nine other German concentration subcamps of KL Natzweiler were established within the framework of the Unternehmen "Wüste" (Desert), i.e. a project for the extraction of crude oil from shale formations. This is why the Germans had begun to build ten oil shale extraction plants along the Zollernalbbahn, i.e. the Tübingen-Sigmaringen railway line, as well as along the Balingen-Rottweil railway line in: Dußlingen-Nehren, Bisingen (KL Bisingen), Engstlatt, Erzingen (KL Erzingen), Dormettingen-Nord, -Süd, -Ost and -West (KL Dormettingen and KL Dautmergen), Schömberg (KL Schömberg), and Zepfenhan (KL Schörzingen); however, they only managed to complete four factories as part of the Außenlager-Komplexes "Wüste." Of the 15,000 prisoners, 3,480 people died (1,158 of whom died in KL Bisingen). In total, there were 4,163 prisoners in KL Bisingen alone, 1,000 of whom were Poles transferred from Auschwitz on 24 August 1944 (could it have been the contingent of Warsaw residents sent there at the beginning of August?), and since 30 October 1944 there was an additional group of 250 Polish Jews from KL Vaihingen-Enz. The following German companies were involved in the project: Kohle-Öl-Union von Busse KG, Deutsche Ölschiefer-Forschungsgesellschaft GmbH, Deutsche Schieferöl GmbH, Deutsche Bergwerks- und Hüttenbaugesellschaft, and the largest of all, IG Farben, see: Ch. Glauning, "Schieferöl und Zwangsarbeit: das Unternehmen 'Wüste' und das Konzentrationslager in Bisingen," in: Konzentrationslager - Geschichte und Erinnerung: neue Studien zum KZ-System und zur Gedenkkultur. Workshop zur Geschichte der Konzentrationslager, 12.-15.10.2000 in der KZ-Gedenkstätte Flossenbürg, ed. P. Haustein, Ulm, 2001, pp. 153-164. 
Johann Friedrich Rohrer as new mayor, who did not oppose the arbitrariness and brutality during the first weeks of the French occupation. ${ }^{10}$

Apart from the instances of French retaliation, the Germans were also targeted by concentration camp prisoners, venting out years of intimidation and humiliation by SS-Totenkopfverbände Wachmannschaften (including experiences during the "death march") with the approval of the liberators:

"Finally, the French army arrived. [They were] very few, called us together and said: 'You are now liberated. You don't have to be afraid anymore. You can do whatever you want. Go ahead and do what you want. And if you find the Nazis [i.e. Germans from the local NSDAP elite], bring them here.' And they gave us ammunition. [The French] entrusted us with responsibility for the village. They gave us machine guns [sic! rifles], pistols, motorbikes and several jeeps. And they set up their headquarters. The other prisoner - he was not a Jew, but a lieutenant in the Polish Army -was appointed chief [commander] because he knew how to organise matters. We went out and we arrested the Nazis [national socialist/ Germans]. And we brought them to the headquarters. We took advantage of the favourable moment - we did to them various things that we always wanted to do."

Dirlewanger himself was massacred and beaten to death as a result of an "investigation" conducted by "Polish guards" during the nights of 4-5 June 1945. His cellmate and German prisoner of war, Luftwaffe Lieutenant Anton Füssinger, mentioned during the interrogation before the officials of the Kriminalkommissariat Ravensburg and the Amtsgericht Saulgau that Dirlewanger had been "administered" justice by the hands of Poles (the significance of this interrogation requires citing it almost in its entirety):

I was in the local prison in Altshausen from 1 June to 5 June 1945 with two other prisoners in the same cell. We introduced ourselves with our family names. One of them turned out to be Gustl [August] Minch, from Oberndorf [am Neckar], the other one presented himself as Dirlewanger without any further information. On the first day I did not learn anything more about him. However, on the second day the Polish concentration camp prisoners working as guards called him "colonel." I asked him what it meant. He then told me that this meant that he was a colonel. Afterwards he answered further questions. Later on, after we stayed together a little longer, he admitted to having served in the Waffen-SS. Since he was arrested because of concentration camp prisoners [who had claimed] that he was the head [commander] of a concentration camp [ZAL Dzikow], as his name was listed on the board at the entrance to the concentration camp, he explained in our presence

10 W. Radlow, "Opfer des Todesmarsches Standort Altshausen," in: Denkorte an oberschwäbischen Erinnerungswegen, Ravensburg, 2017, pp. 76 and 79-81, and H. Willbold, Das Kriegsende 1945 im nördlichen Oberschwaben unter besonderer Berücksichtigung des Altkreises Saulgau, Bad Buchau, 1995, p. 178.

11 V. Mall, H. Roth, "Vom KZ Hailfingen auf Todesmarsch Die Evakuierung der Lager des Unternehmens Wüste," in: Heimatkundliche Blätter Zollernalb, 60, 2013, p. 1829 [after:] USC Shoah Foundation, Interview Irving Wassermann (b. 1924 in Płońsk), Code 2841; 26.05.1995. 
that he was not the commander of the camp, but only temporarily served as a guard with his battalion. [...] In front of the cell door there was a French soldier, a guard in a red kepi [navy blue kepi with a red bottom]. Nevertheless, when I was arrested, I did not see the Frenchman, but rather armed and uniformed Poles. On the next day came [...] a 16-year-old Jew [...] from Ebersbach, Saulgau County [now Gemeindeverwaltungsverband Altshausen], where he lived, and they let him punch us in the face, which he did under the supervision of the Poles until he got tired. We returned to the cell with our faces completely shattered. I myself had been beaten on the same day by the Poles and only because I refused to shout three times: "I am a German pig." Dirlewanger and Munch were pulled out of the cell into the corridor every night and brutally beaten. I heard blows and terrible screams. In daylight, I would see bleeding open wounds on the faces of Minch and Dirlewanger, and their entire bodies were covered with bleeding welts. ${ }^{12}$

The rest of the German prisoner's testimony eventually concludes in the inevitable demise, revealing the brutality of the French occupation in the first post-war weeks: "Minch and Dirlewanger were taken from their cells separately three times on the night of 4-5 June 1945 and beaten in the corridor. After they returned to their cell for the third time, they could no longer speak or stand. After a short time the guards [Wachmannschaften] came to the cell again and ordered them to get up and follow them. Neither Minch nor Dirlewanger could lift themselves. Then the guards [Wachmannschaften] began to strike them with rifle butts in their heads, so that their heads turned into an indiscernible bloody pulp. Then they started kicking them in the stomachs. After that, the guards [Wachmannschaften] left both of them lying in the cell unconscious [...]. I am surprised that according to the registration of death [performed] by the French commandant, Dirlewanger had died only on 7 June 1945, and Minch only on 8 June 1945. It is deliberately erroneous since the document indicates that both had died of natural causes. I can testify at any time in a court under oath that Minch and Dirlewanger died of the wounds sustained during the beating by Polish guards [Polnischen Wachmannschaften]."13

This account is supplemented by the testimony of Betty Angele (née Steinle), a German Red Cross nurse in Altshausen. She informed the officers of the Kriminalkommissariat Ravensburg (Polizeipräsidium Konstanz) that the reason for the arrest was Dirlewanger's lack of necessary documents, as he was in hiding, convalescing in Upper Swabian towns from the injury sustained in February. Her testimony practically matches that of Anton Füssinger: "In the first days of June, I brought dinner to the local prison for Füssinger, who I know from Ebersbach. Today I no longer remember whether I spoke to him about why he had been imprisoned. There were two men in the cell with him. I did not know their names during my visits. Only after their death did I find out that it was

12 BAL B162/16592 fol. 101-102, Materialsammlung Bd. 1, T. 1: Staatsanwaltschaft Ravensburg, Geschechen am 30. Juni 1960 - Füssinger, Anton; 30.06.1960; and H.-P. Klausch, op. cit., p. 315.

13 BAL, B162/16592, fol. 103-104, Materialsammlung Bd. 1, T. 1: Staatsanwaltschaft Ravensburg, Geschechen am 30. Juni 1960 - Füssinger, Anton; 30.06.1960, and H.-P. Klausch, op. cit., p. 315. 
Minch, head of the [local] Gestapo office, and the SS officer Dirlewanger. By looking at him, you might assume he was about 60 years old [actually ten years younger]. At the time, I thought that such an elder person could not be a soldier and I believed that he had been arrested by the French for having no papers on him. During my first visit Dirlewanger asked me whether I knew why he was detained at Altshausen. I replied that I did not know. I then asked where he came from. Dirlewanger replied that he had been in a hospital, and if my memory is correct, he said that he had come from Mengen [a town in Baden-Württemberg, Tübingen district, Bodensee-Oberschwaben region, Sigmaringen county, $23 \mathrm{~km}$ north-west of Altshausen]."14

The brutal torture by Polish guards [Polnischen Wachmannschaften] under unclear circumstances led to the death of the German war criminal Oskar Dirlewanger. We know very little about the French commandants in Altshausen and the newly appointed German mayors of Altshausen: aforementioned Johann Friedrich Rohrer (from April to 7 or 8 June 1945) and Hugo Riegel (from 7 or 8 June 1945 to 31 December 1948), who turned a blind eye to the methods used at the prison. One of them performed his duties on the day of the registration of the death of Dirlewanger and Minch, which took place on 7 June. It should be noted that no one at the Centre de détention d'Altshausen adjacent to Rathaus Altshausen tried to prevent Dirlewanger from being tortured.

Apparently the "Polnischen Wachmannschaften" had a free hand in the administration of "justice" instead of a trial. The French commandant and the German mayor must have known about the torture of prisoners in a building adjacent to the town hall. The French ordered a coffin in the morning of 8 June. They made sure that the coffin would not be opened until the funeral at 11 o'clock. They explained to the summoned Catholic priest Josef Romer that he would hold a service for SS-Oberführer Dirlewanger. The entry in the register of deaths was as follows: "Died because of abuse by the guards" (Gestorben an den Mißhandlungen der Wache). His death certificate was not issued until 19 June $1945 .{ }^{15}$

The only sources we have are post-war testimonies written down 13 years after the war in the presence of a police officer and a court clerk. Two German witnesses, Lieutenant Füssinger and Sister Angele, emphasised the participation of "Poles" or "Polish guards" or simply "guards." These accounts are consistent with each other, and additional facts allow us to supplement our knowledge of the enigmatic fate of Oskar Dirlewanger after the war. Both testimonies emphasised that each time the German criminal and the chief of the local Gestapo had been taken outside the cell, their physical condition was significantly affected. Both died after a few days of "interrogation." Unfortunately, there was no possibility

${ }^{14}$ BAL, B162/16592, fol. 99, Materialsammlung Bd. 1, T. 1: Staatsanwaltschaft Ravensburg, Geschechen am 08. Juli 1960 - Angele, Betty; 08.07.1960, and R. Michaelis, Der Weg zur 36..., p. 13.

15 B. Baur, op. cit. [accessed: 10 Jun 2018]. 
of comparing the German testimonies with the Polish accounts or even the Polish or French documents of military units, not to mention the correspondence between the Poles and their French superior.

In summarising the importance of the above statements, one should pay attention to an important issue: the truthfulness and objectivity of witnesses. However, given the consistency of the narratives presented by the prisoner and the sister of mercy (even remembering their affirmative attitude towards the repressed Dirlewanger), it seems unreasonable to question both accounts about the unspecified "Poles," as the German prosecutors and judges did with the testimonies of Polish witnesses after the war. The archival identification of said Poles turned out impossible. Still, it was possible to accomplish the post-war emergency relocation of one platoon by $25-30 \mathrm{~km}$, which required $5-6$ trucks.

\section{Polish perpetrators?}

The attempt to determine who were the "Polnischen Wachmannschaften" met with a serious problem because of the inquisitiveness of a journalist from the popular-science magazine Focus Historia. During his investigation, the dilettante journalist encountered a wall of reluctance on the part of Colonel Jan Skowron. The highest rank living officer (and, in 1945, second lieutenant and platoon commander in the $1^{\text {st }}$ Company) of the $29^{\text {th }}$ Polish Infantry Group (29eme Groupe d'Infanterie Polonaise, 29ème GIP) in France, and until recently the head of the Association of Former Soldiers of the 1st French Army "Rhine and Danube," he would ignore insistent questions from journalists, thus excluding the chance to explain the murder in Altshausen from this perspective. ${ }^{16}$ Most probably, the Polish guards at the French prison by the Rathaus Altshausen were soldiers of one of the two battalions of pioneers (engineers ${ }^{17}$ ), and later of the 19ème and 29ème GIP. They originated from the Resistance, serving since January 1945 in the ranks of the French $1^{\text {st }}$ Army.

"Until December [1944], these units [Polish units of Forces Françaises de l'Intérieur - FFI] were not recognised and had no legal basis for existence, soldiers were deprived of accommodation compensation, regular food, or allowances for their families." 18 Six months after the liberation of France, the units of the Polish

16 A. Węgłowski, “Dopaść rzeźnika Warszawy,” Focus, 2011, no. 2 (49), pp. 43-48.

17 Sappers ("sapeurs"), also called pioneers or auxiliary engineers, were soldiers' auxiliary troops who performed military engineering duties: breaching fortifications, bridge-building, demolitions, laying or clearing minefields, preparing field fortification and repairing roads or any military constructions. "Sapeurs" were also trained to serve as infantrymen in defensive operations.

18 Centralne Archiwum Wojskowe[hereinafter: CAW], III-2 [Main Political-Education Board of the Polish Armed Forces], 89, fol. 9-10, Bolesław Jeleń, mjr. [Do] Pułkownik Naszkowski, Szef Polskiej Misji Wojskowej we Francji, Paryż - Dane o Polskich Zgrupowaniach Piechoty 1-szej Armii Francuskiej; 12.08.1945. 
pro-communist "Free Rifles and Partisans - Immigration Labour Force" (Francstireurs et partisans - main-d'œuvre immigrée - FTP/MOI) were transformed into two four-company infantry battalion-sized Groups (according to Gerhard and Stańczyk, while Zamojski suggests that there were seven companies). The majority of officers and non-commissioned officers were members of the Parti Communiste Francais (PCF). For this reason, the French initially wanted to enrol them in the Foreign Legion. As an indirect variant, the order No623/I/CH/I lère Armée Française, Bureau I, subordinated the Poles to Lieutenant Colonel Huret, the commander of the "colonial" unit of the $201^{\text {st }}$ North African pioneer regiment (201ème régiment de pionniers Nord-africains - 201ème RPNA). ${ }^{19}$ Initially, the Poles were to be assigned to each battalion by companies. Only in April 1945 were the Polish battalions reorganised under the official command of Major Henri Thevenon, who was treated by the Polish communists as a French liaison officer. Their Polish superior was Major Bolesław Jeleń, who had been appointed on behalf of the communist Polish Committee of National Liberation (Polski Komitet Wyzwolenia Narodowego - PKWN). However, he himself reported: "We agreed to a French commander for the entirety of both Groups, and that is Major Thevenon. Major JELEN Bolesław is his deputy as the Polish commander of both Groups."20

The Poles from the northern departments were directed to the $19^{\text {th }}$ Polish Infantry Group (19ème Groupement d'Infanterie Polonaise, 19ème GIP) under the command of Major Bolesław Maślankiewicz. The unit consisted of the $5^{\text {th }} \mathrm{com}$ pany under Lieutenant Julian Nowak, $6^{\text {th }}$ company under Lieutenant Władysław Kaczmarek, $7^{\text {th }}$ company under Lieutenant Jan Kaczmarek, and $8^{\text {th }}$ company under Lieutenant Józef Oleg. The 19ème GIP consisted of Polish volunteers from Séclin near Lille, Geusnain near Douai, or Hérin near Valenciennes. The "Southern" 29ème GIP of Major Jan Gerhard (Ghérard) consisted of the $1^{\text {st }}$ company under the command of Lieutenant Tadeusz Marcinkowski, $2^{\text {nd }}$ company under Lieutenant

19 AAN, 408/ III-8 [Resistance Movement of the Polish Left in France, 19th and 29th Groups of the Polish Infantry at the French 1st Army], fol. 7, Polskie Siły Zbrojne we Francji. Polskie Zgrupowanie Piechoty przy I-ej Armii, n.d.; SHD Vincennes, 12P/293, fol. 6 [Unités d'étrangers - Forces Militaires Polonaises en France: Bataillon Polonaises Topor, Bataille Polonaises de la Loire, 19eme compagne polonaise], no fol. Service historique, Section "C”, Poste 134, A l'attention du Colonel Pavelet charge de la synthèse des renseignements concernant les formations d'étrangers - Formations d'étrangers sous commandement Français ou Allié; 16.07.1957; and H. Stańczyk, "Zgrupowania Piechoty Polskiej we Francji," in: Wojskowy Przegląd Historyczny, 1981, no. 4 (98), p. 205.

20 It should be noted that Jan Gerhard replaced Major Maślankiewicz as commander of the 29ème GIP "by order of the party authorities." Initially Gerhard was to assume command of the 19ème GIP, "but the officers of this battalion did not want to accept Gerhard as their commander as they did not know him [sic!]. I know from conversations with officers of the Polish Infantry Groups that Gerhard was disliked both by soldiers and officers for harsh discipline and improper attitude," see: AAN, 408/ III-8 [Resistance Movement of the Polish Left in France, 19th and 29th Groups of the Polish Infantry at the French 1st Army], fol. 7, Polskie Siły Zbrojne we Francji. Polskie Zgrupowanie Piechoty przy I-ej Armii; AIPN, BU 2386/14476, fol. 265, Protokół przesłuchania świadka - Maślankiewicz Bolesław; 1.03.1954, and H. Stańczyk, op. cit., p. 205. 
Henryk Karczewski, $3^{\text {rd }}$ company under Lieutenant Marceli Drabik and $4^{\text {th }}$ company under Lieutenant Edward Mazgaj. The second battalion (29ème GIP) consisted of Polish communists from FTP-MOI operating in Southern France: Montceau-les-Mines, St. Étienne, Lyon and the Reuilly barracks in Paris. The so-called "party plenipotentiaries" in each of the battalions and companies of the 19ème GIP and 29ème GIP were proscribed by the French, but they were still present and conducted politicising activities. "Virtually the entire crew of both groups were workers, including non-commissioned officers and officers, issued from economic emigration that had settled in France even before the war," as Major Jelen described it. Major Maślankiewicz's battalion was equipped with only 150 Mauser bolt-action rifles ("carbine 98 short") - and the second battalion with only 350 Mauser Kar98k and basic tools for manual work, boldly referred to as pioneer (pionnier) equipment. ${ }^{21}$

Both units retained their national character, with the introduction of political officers and the recognition of the pro-Soviet State National Council (Krajowa Rada Narodowa - KRN). The Poles' main duty was to secure order in the rear zone of the French $1^{\text {st }}$ Army, in the ranks of which they were sent from Alsace to the Black Forest and Württemberg, and some to Lake Constance. As Major Jelen reported: "The units took part in the operations of the $1^{\text {st }}$ French Army as rear units (pioneers), as security [guards] of warehouses, providing supplies to line units - occupation, consequently having no combat experience." The end of the war caught them close to the Swiss border, in Singen near Constance. In one of the French $1^{\text {st }}$ Army's orders of battle both Polish units were included in the "labour force" section (main d'œuvre) and were designated as the 19ème, 29ème Groupements de travailleurs polonais (Groups of Polish workers). ${ }^{22}$

${ }^{21}$ The party plenipotentiaries (i.e. political commissars) were members of the PCF and prewar Communist Party of Poland (Komunistyczna Partia Polski - KPP): 29ème GIP Cpl. Michał Kloska, $1^{\text {st }}$ Comp. Rifleman Leon Kabaciński, $2^{\text {nd }}$ Comp. Rifleman Alojzy Lewandowski, $3^{\text {rd }}$ Comp. Rifleman Andrzej Herbowy, $4^{\text {th }}$ Comp. Jan Krzakala; 19 ème GIP Zygmunt Bogdan, $6^{\text {th }}$ Comp. $2^{\text {nd }}$ Lt. Feliks Kostrzewa, $7^{\text {th }}$ Comp. Piotr Andrzejewski, see: AAN, 400/I-9, fol. 32, Spis pełnomocników partyjnych; bd. and CAW, III-2-89, fol. 9-10 and 11, Bolesław Jeleń, mjr. [Do] Pułkownik Naszkowski, Szef Polskiej Misji Wojskowej we Francji, Paryż - Dane o Polskich Zgrupowaniach Piechoty 1-szej Armii Francuskiej; 12.08.1945.

${ }^{22}$ Pioneer (Pionnier) is a soldier employed to engineering and construction tasks. The term is in principle similar to a sapper. The 201ème RPNA was not a combat regiment of French sappers (Régiment du Génie français) but a Regiment of pioneers (Régiment de pionniers), vide: Archiwum Akt Nowych [hereinafter: AAN], 408/ III-8 [Resistance Movement of the Polish Left in France, 19th and 29th Groups of the Polish Infantry at the French 1st Army], fol. 8, Polskie Sily Zbrojne we Francji. Polskie Zgrupowanie Piechoty przy I-ej Armii; bd; CAW, III-2-89, fol. 9-10, Bolesław Jeleń, mjr. [Do] Pułkownik Naszkowski, Szef Polskiej Misji Wojskowej we Francji, Paryż - Dane o Polskich Zgrupowaniach Piechoty 1-szej Armii Francuskiej; 12.08.1945; SHD Vincennes, 10P/193-22, Ja/3, fol. 12, lére Armée Française, 3eme Bureau, No 2.779/3-TS, Stationnement des Unites de la lére Armée Française a la date du 31 mai 1945; J. Rutkiewicz, "Zapomniani żołnierze roku 1945," in: Mundur i Broń, 2001, no. 1 (6), pp. 20-21 and H. Stańczyk, op. cit., p. 204. 
Initially, the former Resistance fighters FTP-MOI wore English and pre-war French uniforms Model 1935. Berets, side caps and French helmets M-1915 prevailed as headgear. Later, the 19ème GIP and 29ème GIP received winter service for the French from American deliveries: uniforms M-1941, equipment M-1910, shoes M-1943 and M1 helmets. They were distinguished by white-and-red pennants and eagles (crownless), and the left shoulders of their jackets and coats bore the patch of the French $1^{\text {st }}$ Army (coat of arms of the city of Colmar with the inscription "Rhin et Danube"). The armament of the 19ème and 29ème GIP consisted of German weapons, seized or supplied by the French. ${ }^{23}$

\section{Relations within Polish Infantry Groups}

There are many indications that the 19ème GIP and the 29ème GIP were not genuine military units. The officers of both groups became officers in a discretionary manner, according to their merits in the Resistance. The examples of behaviour presented below stood in total contradiction to the classical understanding of military service; the restrictions imposed by Marxist patterns of thought led to an aberration of ethics and honesty. The communists from the officer cadre of both units did not accept any opposition (which they identified as prewar "Sanation" - "Sanacja") and immediately banished all opponents from their ranks, thus securing a monopoly of command: this way Lieutenant Dziedzic was removed for making a number of statements hostile to People's Poland and for the organisation of night manoeuvres in the streets of Tuttlingen under the guise of exercises, which brought the entire garrison into a state of emergency and was an explicit provocation aimed at discrediting the Groups in the eyes of the French authorities. "[Lieutenant Jerzy Dunin-]Żupański and [officer Feliks] Malanowski were expelled for hostile remarks and for undermining trust in the Groups' command and announcing that they would not return to Poland and advising the soldiers to do the same." ${ }^{24}$

The same situation occurred with Captain Michał Gargol, Captain Franciszek Kardacz and Warrant Officer (chorąży) André Kłak; in total the communists removed 24 people from both Polish battalions. Of course, the official reasons were thievery, fraud, swindling and drunkenness. Meanwhile, the second list included as many as 110 people from the 29ème GIP and 56 released from the 19ème GIP, with the majority of them refusing service at a level lower than what they had reached in the Resistance. ${ }^{25}$ For instance Captain Gargol "attempted to instigate

23 S. Komornicki, Wojsko Polskie 1939-1945. Barwa i broń, Warszawa, 1984, p. 238 and J. Rutkiewicz, op. cit., pp. 22-23.

${ }^{24}$ AIPN, BU 2386/14481, fol. 168v, Notatka służbowa z przesłuchania podejrzanego Gerharda w dniu 15 września 1954.

25 AAN, 408/ III-3 [Resistance Movement of the Polish Left in France, 19th and 29th Groups of the Polish Infantry at the French 1st Army], fol. 9-11, Oficerowie i podoficerowie usunięci 
a looting for his personal benefit, was dishonest towards his superiors, was frequently caught lying and deceiving his superiors." 26

The story of the murder of Lieutenant Grycel in the autumn of 1945 was more serious; "[...] he had decided, in concert with several other officers removed from the Groups, to file a report to the command of the French $1^{\text {st }}$ Army in Freiburg that the command of the Groups had transferred a significant amount of gold from a German bank [Deutsche Bank?] in Kehl to the Polish government [PKWN]. Grycel claimed that the officers with whom he was cooperating and he himself had proof of this transfer, which constituted a serious crime in the eyes of the French authorities, as all the reserves of gold seized from the Nazis [Germans] were considered property of France. In his operation, Grycel wanted to rely on the transfer of a certain amount of typewriters, office supplies and a few decorative silver and gold objects from the command of the Groups to Col. Marian Naszkowski [Head of the Polish Military Mission in Paris] to set up the embassy in Paris. Some of these objects came from the confiscation of the loot by Colonel Jelen among the soldiers of the 19ème GIP, and the looted objects came from the bank in Kehl. ${ }^{27}$ Grycel wanted to found his operation on the basis of this fact, which was all the more dangerous as it would be difficult for the Command of the Groups to prove what exactly was in this bank." 28

During their encounter, the three commanding officers, Jeleń, Gerhard and Maślankiewicz, decided Grycel would be eliminated at the military training ground in Horb. Jelen entrusted the murder of Gerhard's opponent to Captain [Antoni] Chrost and Captain [Józef] Migos, and the execution spot was chosen

z 29 Zgrupowania Piechoty Polskiej przy Francuskiej Armii Okupacyjnej; bd.; fol. 12-14, Zwolnieni z 29 Zgrupowania Piechoty Polskiej przy Francuskiej Armii Okupacyjnej; bd. [104 persons dismissed on disciplinary grounds and six persons for health reasons at their own request] and fol. 15-16, Zwolnieni z 29 Zgrupowania Piechoty Polskiej przy Francuskiej Armii Okupacyjnej; bd. [56 dismissed].

26 AIPN, BU 2386/14464, fol. 140, Wojsko Polskie, Okr[ęgowy] Zarz[ąd] Informacji Nr I, Nr A-3752 - Do Szefa II-go Oddziału Głównego Zarządu Informacji Wojska Polskiego, płk Krzemienia; 31.12.1948.

27 On one hand, Kehl was a town evacuated by the Germans in October 1944 - an infantry regiment and 40 policemen stayed behind to protect the depopulated town. The subunit remaining in Kehl was withdrawn on 13 April. The French crossed the Rhine at Germersheim and headed south between the Rhine and the Black Forest (Schwarzwald).

On 15 April 1945, a French infantry unit from Eckartsweier was able to take over Kehl without resistance and captured the police officers who remained in the town. On the other hand, after the advancing troops of the French 1st Army passed through the town, the day of 17 April 1945 saw numerous acts of violence, arson, looting and hundreds of rapes. The officers were only able to discipline the soldiers after two days. The planned further offensive was delayed and could not start until 19 April, see: Hartmut Stüwe, Kehl im Dritten Reich. Stadtgeschichte 1933-1945, Kehl am Rhein, 1995, p. 165.

28 AIPN, BU 2386/14481, fol. 169v-170, Notatka służbowa z przesłuchania podejrzanego Gerharda w dniu 15 września 1954. 
by Maślankiewicz. The above-mentioned "officers" arrested Lt. Grycel and locked him in the basement of the staff building. He was guarded by one of the warrant officers (and later an officer of the Ministry of Public Security [MBP]). Colonel Jeleń informed the party organisation in Paris and Colonel Naszkowski about his decision for approval. ${ }^{29}$

The murder of the Polish officer by the "commanders and officers of the Group" proceeded as described by one of the killers, who probably wanted to prove himself to the officers of the Main Directorate of Information of the Polish Army (Główny Zarząd Informacji Wojska Polskiego, GZI WP): "Several days later [after the arrest], Gerhard and Chrost removed Grycel from detention around 10 p.m., telling him that he would be transported to Horb, where the investigation into his case would be continued, as there were witnesses there in the 19ème GIP whom Grycel had invoked. Shortly afterwards, Gerhard, Chrost and Migos together with Grycel left for Horb by car. Captain Chrost was driving, Grycel was sitting next to him, while Gerhard and Migos were sitting in the back. According to their plan, Grycel was to be stunned by Migos with a blunt instrument at the entrance to the Horb military training ground, as he would have realised at that turn that he was not being taken to the barracks, but to an empty military training ground. At the turn to the training ground, Grycel was stabbed by Migos in the head with a blunt instrument and stunned, and then brought to the execution site. However, Grycel unexpectedly regained consciousness there and started to run away. A moment later, he was shot simultaneously by Chrost, Gerhard and Migos from their guns. After the execution, Grycel's corpse was thrown by Gerhard, Chrost and Migos into a dozen-meters deep faecal pit at the training ground, where he drowned." The gangster method indicates that for communists, depriving a human being of their life was not a concern, and the manner of covering up the traces indicates criminal conduct on the part of the officer cadre of the 29ème GIP. And at the same time, the partners in the crime, Jelen and Chrost, were able to conceal the facts in favour of one of the accomplices in the murder of the enemy of the people from the agents of the Main Directorate of Information of the Polish Army (Główny Zarząd Informacji Wojska Polskiego - GZI WP). ${ }^{30}$

Other communists serving in the 19ème GIP and 29ème GIP presented a similar approach, as could be inferred from Lieutenant Piasecki's four-page report. The document referred to the issue of placing the Polish Infantry Groups at the disposal of the command of the American $3^{\text {rd }}$ Army: "We will not allow this to happen and we must react immediately. However, we lack people to carry out the sentence on the traitors. And so we think that you, Palczyński and Piasecki, as

29 AIPN, BU 2386/14475, fol. 307-308, Notatka służbowa z przesłuchania podejrzanego Gerharda w dniu 15 września 1954.

30 AIPN, BU 2386/14481, fol. 170-171v, Notatka służbowa z przesłuchania podejrzanego Gerharda w dniu 15 września 1954. 
communists, will agree to enforce this sentence. Palczyński and I agreed, although Captain Kardacz would not disclose the names of these alleged 'traitors.' And from that day on, Captain Kardacz and Warrant Officer Kłak would invite me for private chats, where they would tell me over a bottle of vodka about the tasks of a communist; that one had to be tough, vigilant, reveal traitors and 'dispose of them.' Captain Kardacz used to say that shooting a traitor is the best way to eradicate the turncoats and servants of the West as soon as possible. I do not know whether these 'traitors' (as I later found out: Major Jeleń, Major Gerhard and Captain Katz) actually intended to put us at the disposal of the American $3^{\text {rd }}$ Army." Rivalry in the ranks of the 19ème GIP and 29ème GIP and the attempts at a mutual elimination of enemies (most often imaginary) belonged to the everyday life of Polish communists. ${ }^{31}$

It should be added that the ruthlessness of Officer Gerhard was not limited to class enemies, since he planned to eliminate his direct superior, and the lack of consent from "Władek" [Lt./Cpt. Michał Gargol] (later a UB agent), led to his removal from the group: "Major Gerhard kept on meeting with one officer of the Polish forces in Rotwoil [Rottweil], where they discussed secret matters of both groups. Following his order, an assassination attempt was organised against Jeleń and Żupański so he could take the power in his own hands. When I drew his attention to this deed, he filed a report on me to Col. Petch, who was his commander and mine, about my dismissal from the unit. After a longer consultation between Petch and the commander of $201^{\text {st }}$ R.P.N.A. Huret, who called for me and ordered me to apply for demobilisation, as it was required by the French Bureau VI in coordination with the English Bureau." 32 The testimonies of another "officer" included in a note by a UB agent suggest low morale among the Polish battalions: "Lt. Zgorzelak, former employee of the M.B.P. and now an employee of the enterprise 'Ruch' in Szczecin, was questioned among others; as he provided some details on the immoral behaviour of Gargol, he stated that the same can be said of many other officers of the 29ème GIP."33

Gerhard himself began to accuse (probably under the influence of torture by "Informacja Wojskowa" officers) Cpt. Gargol, although the methods he suspected him of were similar to those which he himself could have used during the occupation in Württemberg: "1/ Cpt. Gargol was a so-called 'looter' in the most unpleasant sense of the word, he traded in cars, but he did not despise minor trade. [...] 4/ During his stay in Germany, Cpt. Gargol Michał concealed the fact that he had been maintaining social relations with the families of known Nazis from the area (especially women), causing the soldiers' indignation. I remember several reports

${ }^{31}$ Cpt. Kardacz gave Lt. Piasecki and Sgt. Palczyński one 15-shot 9mm pistol each, vide: AIPN, BU 2386/14464, fol. 187-188, Sprawozdanie por. Piaseckiego pt. „Sprawa zamachu”; 25.01.1950.

32 AIPN, BU 2386/14481, fol. 315-316, Raport Władka [o Gerhardzie]: bd.

33 AIPN, BU 2386/14481, fol. 326-327, Ppłk E. Leśniewski, Notatka informacyjna; 26.01.1953. 
of soldiers on this subject. [...] 6/ I believe that it was with Cpt. Gargol Michał that we once had a dispute regarding a robbery at gunpoint in a German house. However, I am not entirely sure about this fact." 34

In addition to serious accusations against the Polish Groups, post-war testimonies sometimes provided information confirming that the communists treated the area as a site where they could gain a fortune. The envy they felt due to not receiving even a fraction of the Württemberger loot led to "exposing" before the GZI WP of an unworthy member of PCF/PPR/PZPR: "I personally came into contact with GERHARD only in 1945, I do not remember the date in any more detail, but it was already after the liberation in Paris. At that time he was in the Polish Infantry Group under Col. [Mjr.] JELEŃ. I met him accidentally, leaving the building of the Central Committee of the Communist Party of France, where I was working. I do not know why he was in Paris at the time, because I did not ask him about it. In a short conversation we had with each other, I asked him to procure for me a good camera, provided that he would still be in Paris, as I knew from his companions that he was bringing various loots from Germany for his wife, Etę CATARINE [sic, actually Catherine Varlin, née Judith Haït-Hin]. ${ }^{35}$ The fact that Major Gerhard was engaged in looting was also mentioned by Lt. Piasecki: Cpl. Walczak and MCpl. Banach told me in 1945 that Major Gerhard was involved in looting in Germany after the end of the war. I do not know whether this is true." ${ }^{36}$

The relations prevailing at the 29ème GIP were discussed in the testimony of one of the officers of this battalion, aforementioned Lieutenant Skowron. The 1950s were a time when younger and lower rank officers would often submit unfavourable comments about their commanders to the organs of the GZI WP: "I can say that as far as the soldiers of the 29ème GIP are concerned, they considered Gerhard to be unfair, as he very often punished soldiers for trivial matters quite severely, and there were cases when he even punished them wrongly, which caused dissatisfaction among the soldiers. The discontent among the soldiers of the Group was also considerable due the fact that GERHARD introduced a discipline similar to that of the Sanation Army and did not reckon with lower-rank soldiers. [...] The dissatisfaction among the soldiers resulted also from the fact that GERHARD quite often carried out inspections in the soldiers' rooms and took away their per-

34 AIPN, BU 2386/14481, fol. 320-321, Ppłk. Jan Gerhard, Oświadczenie, Dotyczy: Kpt. Gargola Michała; 17.01.1950.

35 As he did not "procure" a camera, Alina Puterffian vel Nina Puterflam went so far as to notify the Military Information that "Gerhard had 'stuck his fingers' in the assassination of [Pierre Georges "]Colonel Fabien[']" and described him as "a man of exorbitant ambition who was able to 'advance even over the bodies of his comrades."' see: AIPN, BU 2386/14464, fol. 212, Załącznik nr 1. Rozpracowanie figuranta A.R.P. o kryptonimie „Ślepiec” ppłka Gerharda Jana; bd.; BU 2386/14476 [Główny Zarząd Informacji Wojska Polskiego, Akta śledztwa - odpisy - Protokoły przesłuchań świadków w sprawie Gerharda Jana, s. Jana], fol. 61, Protokół przesłuchania świadka - Górska Maria /Puterffian Alina/; 11.12.1953.

36 AIPN, BU 2386/14464, fol. 191, Sprawozdanie por. Piaseckiego pt. „Sprawa zamachu”; 25.01.1950. 
sonal [sic!] belongings, pretending that they came from war trophies." This is yet another element pointing to the scandalous behaviour of Polish communists in occupied Württemberg, which they saw as their private Eldorado to which they were entitled. An additional trace of the practices that were unacceptable for the Polish uniform was Skowron's reminiscence of their joint journey to Paris in order to transfer two Citroën cars to the military attaché of the Polish embassy, during which "[...] Gerhard was also bringing to Paris some 4 or 5 suitcases, but I do not know what was in them and for whom they were intended." ${ }^{37}$ If we link these testimonies to the accounts of Maria Górska, an image akin to a criminal group begins to emerge. The communists understood that they had found themselves in a "land of milk and honey." Criminal activity involved a hierarchy, so the removal of Captain Jacques Katz should not come as a surprise; he was accused of "looting," as Gerhard testified, or, according to the official explanation, for "attempting to use his military position to obtain material personal gain." 38

In the case of Cpt. Katz, there was also the matter of anti-Semitism, which manifested itself among the poorly informed members of the PCF, and was an additional source of conflict in the competition for stolen German property: "[...] this Katz guy sent a whole sack of shoes and clothes and furs to Lille to his Jewess to sell [the original note contained a number of grave spelling errors]." Bolesław Jeleń's and Bolesław Maślankiewicz's response to these accusations was telling, as it signalled widespread thievery among their soldiers: "Katz is the scapegoat, of course, because he is a Jew. I can confidently declare that Katz did not send any sacks of shoes or clothing to his wife. Even if he had sent a parcel, it would have been his own belongings brought from Nord and some food for his children. But he did not steal this food from our soldiers. When he was able to put aside his dry portions and a few chocolate bars that he had not eaten himself, none of the soldiers suffered for it, only Katz had saved them for himself. It was Oleksy who was found to carry 3 pairs of military shoes at the moment of departure, which could only come from theft at the company's warehouse or from the soldiers." ${ }^{39}$

Ultimately, Major Maślankiewicz reported: "When we arrived to the site, we found ourselves surrounded by the [French] Foreign Legion, which was in a difficult condition, as you already know. The above mentioned officers had not been taking care of their companies, they were pursuing their intrigues, and outside them they were looking for comfortable quarters, women and vodka. They came to me with delegations demanding ultimately that captains Katz and Migos

37 AIPN, BU 2386/14476, fol. 296-297, Protokół przesłuchania świadka - Skowron Jan; 29.03.1954.

38 AAN, 408/ III-3, fol. 10, Oficerowie i podoficerowie usunięci z 29 Zgrupowania Piechoty Polskiej przy Francuskiej Armii Okupacyjnej; bd.; AIPN, BU 2386/14471, fol. 232, Protokół przesłuchania podejrzanego Gerharda Jana; 01.05.1954.

39 AAN, 400/I-9 [Raporty z koszarów polskich ochotniczych sił zbrojnych przy I Armii Francuskiej] fol. 7, Odpis listu O[leksy]M.; 26.03.1945; fol. 6, Drodzy Towarzysze! [List Bolesława Jelenia i Bolesława Maślankiewicza]; 14.04.1945. 
(from Guesnain) be removed from the staff and that Kardacz and Adam be put in their place." 40

However, these candidates were no better: "[...] 2. KŁAK Andrzej from Harnes. [...] He played a double game. A man of very low morals, he tried to rape a woman by threatening her with a grenade. Very greedy for money. 3. BEDNAREK Józef from Gourges, a manipulator and fraudster who wanted to make a fortune in the army through illegal trade, misappropriation of warehouse stock and the sale of petrol." 41 To make things worse, Kłak was searching for a person to commit murder on the communist Cpt. Antoni Chrost: "Kłak called me and told me to dispose of Lieutenant Niemczewski and Warrant Officer Szydlak. I grabbed Kłak by the collar and said: 'I didn't think you were that kind of person, stop [organising] this crime, because if not, I'll put you before a court-martial or I'll kill you myself.' He was pale, but said nothing. All day long I walked with the entire group, so that no one would take revenge on me." ${ }^{42}$

As it turns out, Polish communists were able to oppose orders to commit criminal acts, as Gerhard testified: "In the spring of 1945, I do not recall the date closer, General Ilich [Gen. Ljubo Ilić] visited me at the Polish Infantry Groups near Wissembourg, next to the German-French border: Ilich, who at that time was a military attaché of Yugoslavia in Paris, had learned about my place of stay from Colonel Jeleń's first wife, Wita Jeleń. He travelled to me by car from Paris in the company of some individual of Yugoslavian nationality I did not know and Wita Jeleń. [...] My conversation with Ilich took place in one of the rooms of my battalion's headquarters, in the presence of Wita Jeleń. In this conversation, Ilich asked me to put a few soldiers and a car at his disposal. He explained to me that he needed these soldiers for the following purpose. According to the order given by Tito, Ilich was to organise an action to capture Yugoslavians, supporters of Michajłowicz [Gen. Dragoljub "Draža” Mihailović], a right-wing guerrilla fighter in Yugoslavia and an opponent of Tito. Those captured supporters of Mihailović, who had fled from Tito to Western Germany, were to be transported to Yugoslavia by Ilich to be handed over to Tito's police. According to Ilich, these people were to be kidnapped and forcibly returned to Yugoslavia. The entire operation was to take place in secret from the Allied occupation authorities. The soldiers of my battalion were needed by Ilich for this operation until the arrival of his own people from Yugoslavia. In response to Ilich's request, I stated that as the battalion's commander, subordinate to Col. Jeleń, I cannot make decisions regarding soldiers or cars without his permission. I know from Jeleń that both Ilich and Wita Jeleń

40 AAN, 400/I-9, fol. 21, Bolek [Bolesław Maślankiewicz], Raport o sytuacji w 2-gim Baonie; 20.02.1945.

41 AAN, 400/I-9 [Raporty dotyczące Zgrupowań Piechoty Polskiej przy I Armii Francuskiej], fol. 37, [List Bolesława Jelenia] Drodzy towarzysze; 16.04.1945.

42 AAN, 400/I-9, fol. 42v-42a, Mietek Palczyński, Deklaracja dotycząca machinacji prowadzonych przez chorążego Kłaka i Kapitana Kardacza Franciszka w szóstej kompanii drugiego B.P.P., bd. 
had intervened with him in this matter, but they received a definitely negative answer and Jelen also forbade me to give any people to Ilich, claiming that the undertaking about which Ilich was talking was some kind of trouble in which he would not let the Polish Infantry Groups to be involved." We do not know what it really looked like, especially when we contrast the above words with the testimony of a subordinate of Gerhard: "I also know from my own observation that GERHARD quite often travelled for unknown purposes outside the accommodation area of the 29ème GIP, but where exactly he was going, which sometimes lasted for 3-4 days, that I do not know." 43

The further they went into Germany, the more temptations there were: "[...] I brought a truck loaded with various valuable things in one of the companies, I have no objection to the officers and soldiers taking useful things as a souvenir [sic!], but there were those who had entire warehouses of various things [...], I took away everything they had in excess [...] and if it were possible I would have sent you trucks loaded with machines, cameras, etc..." It should come as no surprise that the majority of these reports, stored in the Central Archives of Modern Records (AAN), and previously collected at the Central Archive of the Central Committee of the Polish United Workers' Party (CA KC PZPR), were protected by a publication ban - obviously enforced outside the list of "party plenipotentiaries." 44

The events taking place in the platoons and companies of the 19ème GIP and 29ème GIP are, of course, part of the post-war reality of Polish communists from the PCF. This was one aspect of the past which should not be mentioned to strangers. The awareness of the lack of documents other than those produced during Colonel Gerhard's interrogations by officers, including agents of the Military Information (with little aid from the remains of documentation of both units from the collections of the CA KC PZPR and files made available at the AAN) may negatively influence the assessment of the presented material. There are frequent objections to the lack of representativeness of the above mentioned type of sources, especially when the disclosure of secrets and conspirators or other previously carefully concealed details took place after torture.

The arrest of Jan Gerhard (real name: Wiktor Lew Bardach) took place more than five years after the events in Jabłonki near Baligród. At that time, as the commander of the $34^{\text {th }}$ Infantry Regiment, Gerhard accompanied General Karol Świerczewski in his military inspection in the Bieszczady Mountains, during which the latter died on 28 March 1947. On 29 September 1952, officers of the Main Directorate of Information of the Polish Army under the Ministry of National Defence, the so-called "Military Information," began a two-year investigation

\footnotetext{
43 AIPN, BU 2386/14470, fol. 23-24, Protokół przesłuchania podejrzanego Gerharda Jana; 10.10.1953, and BU 2386/14476, fol. 71, Protokół przesłuchania świadka - Chrost Antoni; 15.12.1953.

44 AAN, 400/I-9 fol. 18, Moi drodzy [List Bolesława Jelenia]; kwiecień 1945.
} 
based on Gerhard's allegation that he had been falsely accused of participating in the conspiracy and assassination of General Świerczewski, inspired by French intelligence and French emigrants. Was the Colonel of the LWP tortured or was he only threatened by the GZI WP with his execution and repression of his loved ones? To what extent did these threats influence the embellishment of the testimony and did this happen at all?

The question posed is whether the false accusations and the resulting lengthy testimonies before the officers of "Military Information" are worthy of recognition as valuable sources. In fact, until the examination of the documentation from the GZI WP investigation, the amount of source materials which could help describe the background to the events related to Dirlewanger's death, as well as the perpetrators of his execution, was poor. Only the most recent query in the archives of the Institute of National Remembrance (IPN) has revealed a lot of information obtained by "Military Information" during the six months of occupation service under the French forces in Württemberg.

Being unable to use the knowledge and memories of veterans from the Association of Former Soldiers of the French $1^{\text {st }}$ Army "Rhine and Danube" due to excessive omissions or fabrication of their own merits during the fights in Lorraine (29 January-3 February 1945) and the offensive of the $1^{\text {st }}$ Rhine Army towards the Danube (April-May 1945), we were forced to make use of the records from a controversial investigation conducted seven to nine years after the killing of Dirlewanger, although in a completely different case. Usually one-sentence mentions indicate that during their service both battalions, i.e. the 19ème and 29ème GIP, were a part of the reserve of the French $1^{\text {st }}$ Army. Since we were unable to obtain information about the actual events during the war, just as the insistent journalist was with regard to the details of Dirlewanger's death, there is equally little chance we will obtain some recollections covering the nature of the occupation service.

The perception of both battalions has so far been shaped by previous scholarly, journalistic and popular-science texts glorifying the activities of the 19ème GIP and 29ème GIP during the period of communist indoctrination and preventive censorship, as well as those created after 1989. A similar image was established in the consciousness of the members of the Association of Former Soldiers of the French 1st Army "Rhine and Danube." No documents are available in France or Poland. What is astonishing is the lack of correspondence between French superiors and Polish subordinates, and not a single document from the 19ème GIP and 29ème GIP can be found in the French military archive SHD Vincennes, which gives rise to new questions. Has the archive been cleansed of documents concerning the harsh occupation policy of French troops in which the Polish 19 ème GIP and 29ème GIP participated for six months? We could not find any answers to that question.

In fact, the only French document confirming Dirlewanger's death in Altshausen comes from the Chief Commission for the Investigation of German Crimes in 
Poland (Główna Komisja Badania Zbrodni Niemieckich w Polsce) - later the Chief Commission for the Investigation of Hitlerite Crimes in Poland (Główna Komisja Badania Zbrodni Hitlerowskich w Polsce). There is no evidence left in the French archives, and we have checked the documentation of all the French regiments that had been present in the area throughout the service of the 19ème and 29ème GIP in Württemberg. This is also true for the superior structures: divisions, corps, army and French 1st Army military counterintelligence. The two visits to this archive yielded no results, nor did the queries at the Central Military Archive, where no part of the correspondence to or from the 19ème GIP and 29ème GIP or any other documentation has been preserved. There are only memoirs and accounts of some of the commanders and soldiers of both units, dating back to the 1960s and later, which did not add much to the matter of the nature of the occupation service. Similar conclusions were reached following the search for documents from communist organisations and branches in France, which were previously located at the CA KC PZPR. The materials currently made available at the AAN did not provide answers to any of the questions explaining the participation of Poles in the murder of Dirlewanger in Altshausen. Moreover, the discovered handwritten notes make it hardly surprising that the majority of the preserved reports concerning the 19ème GIP and 29ème GIP were banned from publication at the CA KC PZPR - obviously outside the list of "party plenipotentiaries" mentioned above.

Only the testimonies before the officers of "Military Information" brought a lot of valuable details about the nature of the occupation service. However, does the controversial origin of the aforementioned source materials warrant their use for scientific research? It follows from the above that a skilful examination of the testimonies deserves to be considered valuable, even if their intention was to denounce a friend who had failed to provide a stolen Leica camera as a gift. The impure motivations (i.e. envy) of the office employee at the Central Committee of the PZPR do not diminish the importance of her observations.

The fright overwhelming the people interviewed by the GZI WP explains why they opted for presenting their situation in a better light in their own eyes and those of the officers. Because how else can one interpret the detailed description of the murder of Lieutenant Grycel, shot simultaneously by communist officers Chrost, Gerhard and Migos in the autumn of 1945? And if we add to this Gerhard's ruthlessness, which was not limited to class enemies, then we may wonder about the limits of his mercilessness. For what else to call a plot to eliminate one's direct superior? On top of all this, there were the purges, which apart from the mentioned officer Malanowski, WO. Kłak, Lt. Dunin-Żupański, Capts. Gargol and Kardacz, were targeted at almost $10 \%$ of both battalions.

The above facts, unavailable in other archival materials, deserve to be taken into account in the research conclusions. The experience of Polish communists from the PCF, gained during their participation in the French Resistance, was not particularly useful during the military and occupation service. The numerous 
incidents were proof of low morale and discipline. The service in the French occupation forces had a rival in the form of looting, i.e. individual and collective robbing of the German population in Württemberg and other activities unworthy of the Polish uniform. The revolutionary enthusiasm in accordance with the principle inculcated during the meetings with party representatives: "steal what was stolen" left an imprint on the ranks of the 19ème and 29ème GIP.

\section{French troops and Altshausen}

The unit adjacent to the pioneers and Poles was the $9^{\text {th }}$ Regiment of Zouaves (9ème Régiment de Zouaves, 9ème RZ) under the command of LieutenantColonel Adolphe Aumeran, replaced by Lieutenant-Colonel Jean Marie Pernet. The Zouaves, which belonged to French colonial forces, similarly to the pioneers of the 201ème RPNA, were recruited from among the inhabitants of the Maghreb, mainly from Algeria. The first French subunit in Altshausen taken into account can be the 4ème Bataillon of the 9ème Regiment de Zouaves, mentioned in the addressee's headline by Sous-Lieutenant Hoffmann, the French commandant of Altshausen; the commander of this battalion was informed of Dirlewanger's death. And we know nothing more than this short, perfunctory letter hiding the fact of (post)war crime having occurred under French jurisdiction during its occupation mandate. ${ }^{45}$

Meanwhile, we have managed to establish that the soldiers of the 1er Bataillon, 9ème RZ were stationed in June 1945 in Altshausen, and the remaining companies were located in Hoßkirch, $7.5 \mathrm{~km}$ away, and Mengen, $22.5 \mathrm{~km}$ away; from 9 to 17 May the battalion was still stationed in Spöck. The report by Bureau III indicates that the headquarters of the 9ème RZ were located in Ostrach $(13 \mathrm{~km}$ from Altshausen). ${ }^{46}$ Another clue can be found on the Internet, on a French message board dedicated to the Second World War. A discussion devoted to the death of Oskar Dirlewanger made reference to the arrest of the German officer by the soldiers of the 5ème Régiment de Tirailleurs Marocains (5ème RTM de LieutenantColonel Jean Piatte), belonging to the 2ème Division d'Infanterie Marocaine. Unfortunately, it was not based on any of the documents cited above and does not explain whether and how the 5ème RTM then handed over the captured German

45 Of course, there are no documents produced by this occupation unit in the French military archive, vide: AIPN, GK 164/1711, fol. 16-17, GKBZN, Akta w sprawie dr Dirlewanger Oskar, Copie certifies conforme a l'orginal, 30.10.1947; Le Sous-lieutenant Hoffmann, Officier de Garnison de la Place d'Altshausen à Monsieur le Chef de Bataillon, Commandant le $4{ }^{\text {ème }}$ Bataillon du $9^{\text {ème }}$ Regiment de Zouaves; 08.06.1945.

46 One of the companies of I/9ème RZ was stationed in Altshausen since the start of May 1945 the first record refers to the date 7 May, see: SHD Vincennes, 12P/42, [Infanterie], fol. 103-104, JMO [Journaux des marches et opérations] $9^{\text {ème }}$ Regiment de Zouaves, 1er Bataillon du 1.2.43 au $5.7 .45 ; 1.06 .-10.06 .1945$. 
to the 201ème RPNA, 19ème GIP/29ème GIP or 9ème RZ. Little is explained by the list of crimes reported to the gendarmerie (Prévôtés), which provides raw information on the number of crimes committed in June. The number of homicides within the French $1^{\text {st }}$ Army was low in June 1945, amounting to 17, of which two people were killed in the $5^{\text {th }}$ Armoured Division, that is the armoured division to which the aforementioned Zouaves stationed in Altshausen were subordinate; a similar number of homicides took place in the units of the 2ème Division d'Infanterie Marocaine, to which the 5ème Régiment de Tirailleurs Marocains was subordinate. ${ }^{47}$

Shortly after Dirlewanger was killed, the French forces were relocated within the occupied zone. The 201ème RPNA itself was regrouped to Tuttlingen (1er Batl.), Villingen (2ème Batl.) and Lindau (3ème Batl.), while the remaining part of the French occupation forces was sent to Württemberg. ${ }^{48}$ The Poles continued to serve in the Tuttlingen-Horb region and outside Friedrichshafen and Konstanz near Lake Constance. Their superiors were, in May 1945-July 1945, the military commander General Jean de Lattre de Tassigny, and later the military governor Marie-Pierre Konig. The Polish battalions served in the garrisons in Tuttlingen, Lindau, Stuttgart, Karlsruhe, Horb and Baden-Baden until October 1945. This list of localities suggests that the Poles may have also been present in Altshausen, located $68 \mathrm{~km}$ west of Tuttlingen, as well as $53 \mathrm{~km}$ south of Lindau. The service of Polish soldiers gained praise from the Général d'armée Kœnig, commander of the French forces in Germany (Commandant des Forces françaises en Allemagne); he himself paid several visits to Polish troops in Tuttlingen and Horb. Both battalions were part of the French $1^{\text {st }}$ Army until 27 July 1945, and then until 15 October-of the French occupation troops in Germany (Troupes d'occupation en Allemagne, TOA). ${ }^{49}$

47 SHD Vincennes, 10P/193-22, Ja/3, fol. 2, 1ére Armée Française, 3eme Bureau, No 2.779/3-TS, Stationnement des Unites de la lére Armée Française a la date du 31 mai 1945; and 12P/283 [Unités Toutes Armes - 201eme RPNA], no fol. lére Armée Française Commandement des Prévôtés No 2409/2. - Releve de l'activité des prévôtés de la lére Armée Française au cours du mois de Juin 1945; 13.07.1945, and "Mort d'Oskar Dirlewanger: l'unique témoignage," L'Embarasement du monde. Le forum de la seconde guerre mondiale, available at: deuxiemeguerremondia.forumactif.com/t7260-mort-d-oskar-dirlewanger-l-unique-temoignage [accessed: 20 May 2018].

48 SHD Vincennes, 12P/283-22, no fol. 1ére Armée Française, Etat Major - 4e Bureau, No 008859/4IV, Note de Service - Regroupement et démobilisation des Unités de main d'œuvre; 08.06.1945.

49 In addition to the aforementioned Polish unit, Tuttlingen also hosted the headquarters of the 9ème Division Infanterie Coloniale, Parc Mobile Transmissions 830ème, Intendance 303ème, Gestion 322ème, Cie Reparation Eng. Blindes 661ème/2, Hopital Campagne 422ème, see: AIPN, BU 2386/14474, fol. 112-114, Protokół przesłuchania podejrzanego; 10.10.1953; BU 2386/14478, fol. 280, Notatka w sprawie aresztowanego płk Gerharda; 05.01.1954; SHD, 10P/193-22, Ja/3, fol. 12, lére Armée Française, 3eme Bureau, No 2.779/3-TS, Stationnement des Unites de la lére Armée Française a la date du 31 mai 1945, and J. Skowron, "Zgrupowania Piechoty Polskiej 1 Armii Francuskiej „Ren i Dunaj” - 1944-1945,” Kombatant, 2004, no. 6/7, pp. 14-15. 


\section{Attempt at identifying the possible killers of Dirlewanger}

The tally of the units of the French $1^{\text {st }}$ Army has showed the following deployment of the Polish units. The 19ème GIP: headquarters and $7^{\text {th }}$ Company in Kehl, $6^{\text {th }}$ Company in Horb, and $5^{\text {th }}$ Company in Kandel and Villingen. The 29ème GIP was located nearby: headquarters in Balgheim, $1^{\text {st }}$ company in Dürbheim, $2^{\text {nd }}$ company in Tuttlingen, $3^{\text {rd }}$ company in Mengen, and $4^{\text {th }}$ company in Kressbronn am Bodensee. It should be noted that the $3^{\text {rd }}$ company of the 29ème GIP (comm.: Ltn. Drabik) was stationed closest to Altshausen, $24-30 \mathrm{~km}$ to the north-west. ${ }^{50} \mathrm{~A}$ slightly different setting is provided by a French author. The 19ème GIP would be stationed as follows: headquarters and $6^{\text {th }}$ and $7^{\text {th }}$ companies in Horb, and $5^{\text {th }}$ company in Kirchdorf and Villingen. The 29ème GIP would be located nearby: headquarters and $2^{\text {nd }}$ company in Tuttlingen, $1^{\text {st }}$ company in Singen, and $3^{\text {rd }}$ company in Worndorf and Oberschwandorf. The two latter villages were located a bit farther from Altshausen, $47-51 \mathrm{~km}$ to the west. We have not succeeded at accessing the document of the French command produced during a period of twenty days at the turn of May and June and addressed to the headquarters of the 19ème or 29ème GIP. Polish guards may have gone to Altshausen due to a request to send a team or platoon from one of the Polish infantry units to temporarily strengthen the forces subordinate to Lieutenant Hoffmann from "Sûreté" (Police nationale). ${ }^{51}$ Meanwhile, Gerhard himself testified: "together with the 29ème GIP, I have been relocated to Balgheim, and the Group headquarters, together with Major JELEN and Major THEVENON, moved to Tuttlingen a dozen kilometres from my stopover." The route from Balgheim to Altshausen is a $75 \mathrm{~km}$ long hard surfaced road. ${ }^{52}$

The only trace explaining Dirlewanger's route to prison is the information from 3 June: "During the pursuit operation, four Wehrmacht soldiers dressed in civilian clothes (including one SS adjutant) were arrested in Altshausen." This is not much, but at least it shows the methods of the French occupation, which succumbed to the post-war fashion for constant suspicion. This document shows only on a micro-scale the operation of capturing former soldiers of the German armed forces..$^{53}$ At the same time, the lists of POW sections reflect the scale of these activities in the entire French occupation sector. Three divisions of the $1^{\text {st }}$ Army (2ème DIM, 4ème DMM and 5ème DB) arrested 202 German soldiers in a period of 11-12 days following the end of the Second World War, including only seven

50 SHD, 10P/193-22, Ja/3, fol. 12, lére Armée Française, 3eme Bureau, No 2.779/3-TS , Stationnement des Unites de la lére Armée Française a la date du 31 mai 1945.

${ }^{51}$ G. Soufflet, "Les GIP de la Forêt Noire à Varsovie...," Résistance polonaise en Saône-et-Loire, available at: https://www.respol71.com/les-gip-de-la-foret-noire-a-varsovie [accessed: 14.10.2016].

52 AIPN, BU 2386/14475, fol. 89, Protokół przesłuchania podejrzanego Gerharda Jana; 03.05.1954.

53 SHD Vincennes, 10P/193-22, fol. P/5, lére Armée Française, 3eme Bureau, No 2.742/3-TS, Compte - Rendu d'operations de 21200 B au 31200 B; 03.06.1945. 
Waffen-SS privates. ${ }^{54}$ On the other hand, data concerning POWs of the $1^{\text {st }}$ Army from two years later includes a mention of the capture, in the period from 26 May to 1 June 1945, of 348 officers and 7,210 NCOs and privates, while by 8 June the number had decreased to 119 officers and 1,471 NCOs and privates. However, the earlier wartime numbers of German POWs of the French $1^{\text {st }}$ Army are much larger. The French took a total of 142,000 POWs, including 115,275 Germans, between 15 March and 21 May 1945 (25 generals, 3,605 officers and 111,645 soldiers).$^{55}$ But the most important information seems to be the number of prisoners in two POW camps: 3,347 in Cage No. 2 Tuttlingen and 1,225 in Cage No. 3 Lindau. These two towns seem particularly important, but unfortunately we do not know whether Poles from the $2^{\text {nd }} / 29$ ème GIP served as camp guards at Cage No. 2 Tuttlingen $(60 \mathrm{~km}$ west of Altshausen) and similarly whether soldiers of the $4^{\text {th }} / 29$ ème GIP from Kressbronn am Bodensee served at Cage No. 3 Lindau (46 km south of Altshausen) located $7.5 \mathrm{~km}$ from them. ${ }^{56}$

A regional book about Tuttlingen may serve as an additional clue. The numerous death sentences from 1945-1946 indicate that the French military justice system was particularly strict in the post-war period. The main task of the Dépôt d'Armée (Cage d'Armée) No. 2 POW camp in Tuttlingen, described in May 1945 by its commandant Capitaine Rousseau, was to identify Wehrmacht and Waffen-SS soldiers involved in war crimes, single them out of the mass of POWs, and arrest them. They obtained the necessary information from "Polish elements" (d'élements Polonais), which provided valuable services. The Polish men, according to the German author, had forcibly been conscripted into the Wehrmacht, and were now employed by the French as military police at the camp (Police Militaire P.M.). At the same time, the camp chronicle indicates that the guards were to be soldiers of the 201ème RNAP and the 202ème RNAP, which brings us very close to the 29ème GIP in particular.

${ }^{54}$ SHD, 10P/141, [1ére Armée Française, 2eme Bureau, Section Prisonniers de guerre] no fol., 1ére Armée Française, Etat-Major-Section 2/5, Direction du Service des P.G. de la Zone Avant de l'Armee. No 696/2.PG, 3eme Bureau, Etat numerique des troupes ennemies qui se sont rendues apres le 9 Mai a o heures sur le front de la lére Armée Française; 20.05.1945, and no fol., lére Armée Française, Etat-Major-Section 2/5, Direction du Service des P.G. de la Zone Avant de l'Armee. No 708/2.PG, 3eme Bureau, Situation Generale des P. G. depuis le 15 mars 1945 dans la zone de la lére Armée Française; 21.05.1945.

55 SHD Vincennes, 10P/141, no fol., Commandant en chef français en Allemagne. commandement supérieur des troupes d'occupation. Direction P.G. No 259/ 2P.G. Detail des P.G. Captures par la lére Armée controles par les cages d'armee et classes par unite de capture; 05.03.1947 - pp. 7-8.

56 SHD Vincennes, 10P/141, no fol. [1ére Armée Française, 2éme Bureau, Section Prisonniers de guerre], no fol., lére Armée Française, Etat-Major-Section 2/5, Direction du Service des P.G. de la Zone Avant de l'Armee. No 696/2.PG, éme Bureau, Etat numerique des troupes ennemies qui se sont rendues apres le 9 Mai a o heures sur le front de la lére Armée Française; 20. 05. 1945; and no fol., lére Armée Française, Etat-Major-Section 2/5, Direction du Service des P.G. de la Zone Avant de l'Armee. No 708/2.PG, 3eme Bureau, Situation Generale des P. G. depuis le 15 mars 1945 dans la zone de la 1ére Armée Française; 21.05.1945.. 
The German author presumes that these "Polish elements" could have been Volksdeutche from Poland, which led to them being referred to as "Polen-Hans." 57 The Germans imprisoned in Tuttlingen mentioned that one POW of Polish origin from Upper Silesia went by this nickname. After a short time he was already wearing the uniform of a guard, and was later promoted to the position of AdjutantChef, becoming the merciless boss of the guards consisting mainly of Poles and Hungarians. He was then deprived of his post precisely for his brutal methods. The individuals referred to as "guards" by former POWs were the same people who had been initially sent by the French to camps as "Police Militaire." Their task was to escort and guard German prisoners of war while they were working outside the camp, which was clearly transferred to the duties of a group of non-German prisoners of war in Tuttlingen. Among the prisoners of war registered in Tuttlingen in May 1945 for transport to France, there were just under 1,000 Poles and about 500 Hungarians, which made it possible to recruit auxiliary staff. From the outset, the French POW section had serious staffing problems and difficulties in finding the right guards in the POW camps. In order to compensate for this shortage, the French decided to create a "mixed corps of civilian guards in POW camps under military leadership." 58

At the same time, Gehrig did not notice the other side of the problem, as Major Jelen pointed out in his letter: "There is proof that Poles from the Wehrmacht are abused and even killed by the SS at the military POW camps." ${ }^{59}$ Hence, it cannot be ruled out that the threat posed by the Germans triggered the counter-reaction of "Wasserpolacken." It should also be noted that the men recruited this way could also have been forced labourers or prisoners of war, becoming "displaced persons" (DP) after the war. That is why another hypothesis emerges regarding the presence of Poles in Tuttlingen near Altshausen after 9 May 1945, as well as the reasons for their behaviour both in the POW camp and possibly in the occupied town. ${ }^{60}$

For example, the $1^{\text {st }} / 29$ ème GIP, stationed in Singen near the strategically important railway junction, was responsible for the protection of supply warehouses. The $2^{\text {nd }} / 29$ ème GIP was responsible for the Tuttlingen depots (Depot 22ème and Depot 18ème in nearby Dürbheim), and the $651^{\text {st }}$ equipment repair battalion, Etat-Major (EM) 651ème Bataillon de Réparation du Matériel (BRM), was also involved. Then there were the headquarters of the units and warehouses

57 A. Gehrig, "Kriegsgefangenenlager in Tuttlingen 1945-1952: 'Cage d'Armée No 2' - 'Cage C.S.T.O No 2' - 'Dépôt de transit No 2' - 'Bureau de Contrôle et Démobilisation,'” in: Lager Mühlau: 1942-1955, ed. G. Woll, Tuttlingen, 2014, s. 66-67.

58 Astrid Gehrig, "Kriegsgefangenenlager in Tuttlingen 1945-1952: 'Cage d'Armée No 2' - 'Cage C.S.T.O No 2' - 'Dépôt de transit No 2' - 'Bureau de Contrôle et Démobilisation,'” in: Lager Mühlau: 1942-1955, ed. Gunda Woll, Tuttlingen, 2014, s. 66-67.

59 Ibidem.

${ }^{60}$ AAN, 400/I-9, fol. 19, Moi drodzy [List Bolesława Jelenia]; kwiecień 1945, and A. Gehrig, op. cit., pp. 66-67. 
in Rottweill (E.M. Btn. Reparation 653ème, Cie Munitions 62ème, E.M. 633ème Btn. Munitions, Cie Recuperation Materiel de prise 672ème/4) and in Bühlertal, as well as the service carried out in Villingen (Cie Moyenne Repar. Auto 653ème/3, Cie Repar. Engins Blindes 664ème/2, Cie Magasin 24ème Cie/2ème Zouaves). ${ }^{61}$ Other companies had similar duties, combined with patrolling the nearby mountain areas. Their objective was to find the remains of German troops and the mythical Wehrwolf. The war diary of the original Polish regiment indicates that the 201ème RPNA had few duties, and its activity after 10 May 1945 was limited to practice, drills, patrolling and physical work. ${ }^{62}$

\section{Return to the motherland}

Before the departure for Poland a strife broke out between the Polish and French officers. Majors Gerhard and Maślankiewicz did not consent to the "removal from the Groups of Polish Infantry of soldiers for minor crimes, so that they could not leave the country." Both commanders were punished with 11 days of house arrest for insubordination. On 4 November 1945 a railway transport was provided for 1,400 soldiers going back to Poland. They were first transported to Kraków. The commander of the Polish troops told a journalist in Kraków: "Some of them want to return to civilian occupations, but the majority wants to remain in the army wishing-please emphasise this-" said Major Jeleń, "to be allocated to the [Polish] Air Force." The reality of communist Poland turned out to be more mundane. Almost 2/3 of them chose to serve in the force structure of the "People's Government," subordinate to ministers originating from the communist party PPR. The majority of them, 507 men, were directed to the Polish Army (including the $8^{\text {th }}$ Infantry Division fighting against the Ukrainian Insurgent Army [UPA], the Main Information Board of the Polish Army and the Second Board Department of the Second General Staff, i.e. military intelligence), to the Internal Security Corps (Korpus Bezpieczeństwa Wewnętrznego, KBW - 15 officers, 38 non-commissioned officers, 454 privates, from which 71 zealous communists-Stalinists were selected to join the Officers' Political School, thus becoming military political officers, to the Ministry of Public Security (256 men), to the police force - Citizen's Militia

${ }^{61}$ SHD Vincennes, 10P/193-22, Ja/3, fol. 6-11, 1ére Armée Française, 3eme Bureau, No 2.779/3-TS, Stationnement des Unites de la lére Armée Française a la date du 31 mai 1945.

${ }^{62}$ No annotation was found in any war diary of the battalion belonging to 201ème RPNA, to which 19ème GIP and 29ème GIP were subordinate, see: SHD Vincennes, 12P/283 [Unités Toutes Armes - 201 RPNA], fol. 30-31, JMO du Commandant des Forces Prévôtales de la lére Armée Française du 2.2.44 au 31.8.45; 01.06.-11.06.1945; fol. 56-57, 201ème RPNA JMO 3ème Compagnie; 13.07.1945; no fol., 201eme Régiment de pionniers nord-africains, P;.C. de Colonel, N. 1383/H, Confirmation de Message; 22.09.1945, and R. de Salins, Les combats de l'armée française pour la libération: Provence Alsace Allemagne 1944-1945, Paris, 2013, pp. 178-179. 
(Milicja Obywatelska - MO) - 231 men, and the Railway Protection Service (Służba Ochrony Kolei - SOK) - 21 men. In addition, 23 chose to live as military settlers on Regained Territories, 21 went into forestry. The others chose to work in the mining, woodworking or metallurgical industry "emerging from the ruins in a people's democracy." 63

On 18 November 1945, Stefan Korboński, a politician of the anti-communist Polish People's Party (Polskie Stronnictwo Ludowe - PSL), thus described the arrival of the 19ème and 29ème GIP at Aleje Ujazdowskie in Warsaw: "Two battalions of the Polish Army, arriving from France, paraded through the streets of Warsaw. I was standing in front of 'Kruszynka' [a café run by Zofia Korbońska] at ul. Marszałkowska to look at them. Young boys in Allied uniforms [American uniforms M1940], with rifles on their shoulders, were marching quite inertly, looking curiously at the ruins and passers-by. They had stuck some flowers in their barrels and buttons and were clearly waiting for ovations. The crowd, despite the press and radio announcements, was small, and those who came watched the marching men suspiciously and in silence. For who were these soldiers who came from the free world to willingly surrender themselves into captivity? Today we know that this is no Polish Army, but young communists of Polish origin, recruited in France and assigned mostly to the security forces. The people of Warsaw did not fall for it. Since they encountered Soviet officers in Polish uniforms, they have lost all their fondness for that institution. They knew that the list of known deceptions, along the 'consul trick' and the 'diamond trick,' now included a new one: the 'uniform trick." These words are contradicted by the information reported in a trivial article by an apparent uniform expert who claimed that, besides the highest dignitaries of People's Poland, they were greeted by crowds, foreign diplomats and the guard of honour of the Polish Army. Korboński's version was confirmed by a film report from the welcoming and ceremonial parade of our soldiers of the $19^{\text {th }}$ and $29^{\text {th }}$ ZPP on 18 November 1945 in al. Ujazdowskie in Warsaw: the narrow frames focused on cheering crowds, while the only broader shot in the video showed a single group forming two rows of bystanders before the marching soldiers. ${ }^{64}$

${ }^{63}$ The "French" were mentioned by Fighter Ace of the Polish Air Force Lieutenant Colonel Stanisław Skalski, who, after interrogation, was imprisoned in the underground cells of the MBP building on ul. Koszykowa. Men learning Polish words out loud could be heard from the corridor: "These were our guards, the 'French,' who were learning their mother tongue." Another ZPP soldier was visible on a photograph of Gauleiter Arthur Greiser, escorted in June 1946, see: AIPN, BU 2386/14476, fol. 267, Protokół przesłuchania świadka - Maślankiewicz Bolesław; 01.03.1954; H. Stańczyk, op. cit., pp. 209-210; J. Rutkiewicz, op. cit., pp. 22-23, 25; R. W. Słotwiński, "Oddziały polskie z Francji wróciły do kraju. Witamy serdecznie najmilszych braci," Polska Zbrojna no. 245 of 13 November 1945, p. 2, and Jan Zamojski, "Polacy we francuskim i belgijskim ruchu oporu," Wojskowy Przeglad Historyczny, 1967, no. 4, pp. 104-148.

${ }^{64}$ Polska Kronika Filmowa, no. 35/45 (untitled sequence from 00:15 to 01:50); S. Korboński, W imieniu Kremla, Warszawa, 1997, p. 47 and J. Rutkiewicz, op. cit., p. 22. 
Jan Skowron, ${ }^{65}$ however, had doubts about the possibility of Poles being stationed in Altshausen. The psychological repression of a crime on a defenceless POW years after it was committed (which could have been perpetrated by subordinates or colleagues from the unit), even if it were a war criminal or a deviant, is a typical defensive reaction that could potentially have suppressed the crime committed by colleagues from the Resistance or the 29ème GIP. ${ }^{66}$ The stigma of the crime could have marked the participants and witnesses, or even only those who were aware of the assassination of Dirlewanger in Altshausen, for decades. The witnesses may feel embarrassed as they meet the perpetrators of murders, or consider themselves accomplices, knowing they have done nothing with this terrible knowledge for many years. The improvised lynching was an accidental or deliberate execution of justice on the executioner of Belarus and Warsaw in a manner far removed from the standards of Roman law. Its initiators could undoubtedly be inspired by it in later "investigative innovations" in the times of Bierut and Stalin, which allowed them to improve the methods probably already tested in the French improvised prison in Württemberg. ${ }^{67}$ Besides, Colonel Jan Gerhard himself experienced these methods when he was arrested on 29 September 1952 by the Main Directorate of Information of the Polish Army of the Ministry of National Defence. The communist officer was imprisoned for almost two years. He may have had some knowledge of the events in Altshausen, but since he was interrogated only about General Ilich, General Świerczewski and the FrenchUkrainian Banderite conspiracy-rather than the murder of SS-Oberführer Dirlewanger-he did not disclose to the authorities what had really happened in Württemberg. ${ }^{68}$

To sum up, the only possible way to confirm the claim about the "Polnische Wachmannschschsften" in Altshausen at present is to carry out local research among the oldest inhabitants of this Württemberger town. As they were children at that time, they could remember the post-war period of the French occupation,

65 AIPN, BU 2602/18927 (Oddział Attachatów Wojskowych, Teczka personalna Jan Skowron), fol. 3-4 [Nr wych. 160/ OZ/79, Notatka biograficzna - Do Wicedyrektor Protokołu Dyplomatycznego MSZ, Towarzysz Edward Wychowaniec; 06.04.1979; fol. 10 [Płk. dypl. Jan Skowron, Życiorys; bd].

66 The testimony of Major Antoni Chrost, one of the participants in the murder of Lieutenant Grycel, who did not mention one word about the crime before the GZI MON investigating officer, Major Urbaniak, may serve as a symptomatic confirmation of this theory, vide: AIPN, BU 2386/14476, fol. 64-72, Protokół przesłuchania świadka - Chrost Antoni; 15.12.1953.

67 According to the soldiers of the $34^{\text {th }}$ Budziszyn Infantry Regiment, their commander Colonel Gerhard ordered the public execution of a seriously wounded partisan of the Ukrainian Insurgent Army, uncovered during the resettlement operation among an evacuated Ukrainian family. He often ordered the killing of other captured members of the Ukrainian Insurgent Army on the spot, see: Grzegorz Motyka, "Kryptonim 'Bieszczady.' Zabójstwo Jana Gerharda," in: W kręgu «Łun w Bieszczadach». Szkice z najnowszej historii polskich Bieszczad, Warszawa, 2009, p. 158.

68 J. Skowron, op. cit., p. 15. 
seen through their own eyes, as well as acquire knowledge from relatives. The Polish communists from the PCF, who were the officers of the oppressive UB/SB or the military intelligence service, will never reveal the truth; no documents about the perpetrators of the murders in Altshausen have been preserved in the Polish, German and French archives either.

One symbolic fact remains: the subsequent murder of the editor-in-chief of the periodical Forum, Jan Gerhard, by Zygmunt Garbacki and Marian Wojtasik. The violent end given to Gerhard's life by several blows of a blunt object, suffocation by means of a leather strap and several stab wounds with a dagger to the heart. All this resembled per analogiam what had happened in the corridor of the improvised prison in Altshausen.

\section{Abstract}

The article explores all available documents in order to resolve the mystery surrounding the perpetrators of the murder of SS-Oberführer Oskar Dirlewanger. The most important issue was to identify the Polish perpetrators mentioned in two existing testimonies of German witnesses to the events. The only Polish troops operating in the vicinity of Altshausen turned out to be two battalions, the $19^{\text {th }}$ and $29^{\text {th }}$ Polish Infantry Groups (19ème and 29ème Groupement d'Infanterie Polonaise, GIP). One important aspect of understanding the possible involvement of the Polish communists was the demonstration of the many criminal behaviours that impacted the service of the 19ème and 29ème GIP, described in the subchapter "Relations within the Polish Infantry Groups." The location of the French occupation units has not brought any clear answers either; Altshausen was under the authority of the commander of the $9^{\text {th }}$ Zouave Regiment (9ème Régiment de Zouaves).

\section{Bibliography}

\section{Archives:}

Archiwum Akt Nowych

408/ III-3, 408/ III-8, 400/I-9

Archiwum Instytutu Pamięci Narodowej

BU 2386/14464, BU 2386/14470, BU 2386/14471, BU 2386/14474, BU 2386/14475, BU 2386/14476, BU 2386/14478, BU 2386/14481, BU 2602/18927, GK 164/1711, Sz 753/450

Bundesarchiv Ludwigsburg

B162/16592

Centralne Archiwum Wojskowe

III-2-89

Service historique de la Défense - Fonds de l'armée de Terre (à Vincennes)

$10 \mathrm{P} / 141,10 \mathrm{P} / 193,10 \mathrm{P} / 299,12 \mathrm{P} / 42,12 \mathrm{P} / 283,12 \mathrm{P} / 293$ 


\section{Memoirs:}

Erinnerungen an das SS-Sonderkommando "Dirlewanger," ed. Rolf Michaelis, Berlin, 2011.

Korboński S., W imieniu Kremla, Warszawa, 1997.

The SS-Sonderkommando "Dirlewanger": A Memoir, ed. Rolf Michaelis, Atglen, 2013.

\section{Secondary sources:}

Adel und Nationalsozialismus im deutschen Südwesten. Hrsg. v. Haus der Geschichte BadenWürttemberg. Stuttgarter Symposion Schriftenreihe Bd. 11, ed. Ch. Dowe, Leinfelden-Echterdingen, 2007.

Denkorte an oberschwäbischen Erinnerungswegen im Landkreis Ravensburg, Ravensburg, 2017.

Emmrich S., Breucker D., Eitel P., Kriegsende und Neubeginn. Das Jahr 1945 in Ravensburg, Weingarten und Umgebung - Taschenbuch, Ravensburg, 1996.

Klausch H.-P., Antifaschisten in SS-Uniform. Schicksal und Widerstand der deutschen politischen KZ-Häftlingen Zuchthaus- und Werhmachtsgefangenen in der SS-Sonderformation Dirlewanger, Bremen, 1993.

Komornicki S., Wojsko Polskie 1939-1945. Barwa i broń, Warszawa, 1984.

Konzentrationslager - Geschichte und Erinnerung: neue Studien zum KZ-System und zur Gedenkkultur. Workshop zur Geschichte der Konzentrationslager, 12.-15.10.2000 in der KZ-Gedenkstätte Flossenbürg, ed. P. Haustein, Ulm, 2001.

Korboński S., W imieniu Kremla, Warszawa, 1997.

Lager Mühlau: 1942-1955, ed. G. Woll, Tuttlingen, 2014.

MacLean F. L., The Cruel Hunters. SS-Sonderkommando Dirlewanger. Hitler's Most Notorious Anti-Partisan Unit, Atglen, 1998.

Mall V., Die Häftlinge des KZ-Außenlagers Hailfingen/Tailfingen: Daten und Porträts aller Häftlinge, Norderstedt, 2014.

Michaelis R., Der Weg zur 36. Waffen-Grenadier-Division der SS, Rodgau, 1991.

Salins R., Les combats de l’armée française pour la libération: Provence Alsace Allemagne 19441945, Paris, 2013.

Stüwe H., Kehl im Dritten Reich. Stadtgeschichte 1933-1945, Kehl am Rhein, 1995.

Willbold H., Das Kriegsende 1945 im nördlichen Oberschwaben unter besonderer Berücksichtigung des Altkreises Saulgau, Bad Buchau, 1995.

Жуков Д., Ковтун И., Охотники за партизанами. Бригада Дирлевангера, Москва, 2013.

\section{Periodicals:}

Focus

Heimatkundliche Blätter Zollernalb

Kombatant

Mundur i Broń

Polska Zbrojna

Schwäbische Zeitung Altshausen

Wojskowy Przegląd Historyczny

\section{Video materials:}

Polska Kronika Filmowa, no. 35/45. 


\section{Internet:}

L'Embarasement du monde. Le forum de la seconde guerre mondiale, available at: deuxiemeguerremondia.forumactif.com/.

Résistance polonaise en Saône-et-Loire, available at: https://www.respol71.com/.

Hubert Kuberski mgr, graduate of the Historical Department of the University of Warsaw; historian, journalist and filmmaker. Research interests: Balkans, Second World War, "Bandenbekämpfung." Author of: Sojusznicy Hitlera 1941-45. Armie sojusznicze Niemiec na froncie wschodnim i na Bałkanach, Warszawa 1993; "Wschodnioeuropejscy ochotnicy cudzoziemscy w niemieckich oddziałach Ostheer, SS i policji, pacyfikujących Powstanie Warszawskie," Dzieje Najnowsze 2015, no. 3 (h.kuberski@gmail.com).

Submitted 21.03.2019; accepted 15.05.2019 